November - 2007

\title{
Book Review - Good Video Games + Good Learning: Collected essays on video games, learning and literacy
}

\author{
Author: James Paul Gee (2007). Good Video Games + Good Learning: Collected essays on \\ video games, learning and literacy. New York: Peter Lang. ISBN: 978-0-8204-9703-7, \\ paperback, 208 pages, \$29.95.
}

Reviewed by: Sharon Stoerger, Indiana University, USA

Teachers teach that knowledge waits. Bob Dylan, It's Alright, Ma (I'm Only Bleeding)

The perfect is the enemy of the good.

Voltaire

A common 'technology' associated with traditional educational environments is the chalkboard. The teacher stands in front of it and lectures to the students sitting in the classroom. Today's students, though, are experiential learners who multitask and prefer to learn by "seeking, sieving, and synthesizing” (Dede, 2005, p. 7) rather than passively listening. In other words, these individuals learn by doing and are actively seeking out the cognitive challenges presented in video games (Steinkuehler, 2005). Because these students have been exposed to technologies, like video games, educational theories that worked in the past may not in a technology-focused world (Prenksy, 2001).

James Paul Gee could have used Good Video Games + Good Learning as a vehicle to examine educational games or the serious game movement. Instead, he concentrates on well-designed games and the ways in which they can become a context for learning. Gee also examines the lessons that can be learned from video games, including violent ones like Mortal Kombat or Doom. While the media often focus on the violence in these games, Gee argues that they are just like any other technology - alone they are neither good nor bad. Moreover, he asserts, "Effects (good or bad) flow not from the game but from game + context” (p. 3).

In this collection of essays that range in topic from pleasure and learning to the human mind to 'being a professional', Gee's intention is not to suggest that video games can, or should, replace books and teachers. In fact, he believes that the immersive experiences touted by liberal education are not enough; guidance is needed otherwise the learner is "simply left to an infinity of choices with no good way to tell them apart" (p. 79). This is not to say that Gee is advocating for a conservative education approach - one that focuses on the acquisition of facts and standardized tests. Rather, Gee contends that good video games are ones that are challenging yet doable, and through guidance can help learners "prepare for action” (p. 80). 
Book Review - Good Video Games + Good Learning: Collected essays on video games, learning and literacy

One of the strongest sections is Gee's discussion of affinity spaces in Chapter 8. He describes the concept of affinity spaces as an alternative to "communities of practice" that are presented by scholars such as Lave (1996) and Wenger (1998). As Kling and Courtright (2003) astutely point out, the term "community" is one that is often uncritically used in layman's terms to connote "a group which shares warm, caring, and reciprocal social relationships among its members" (p. 224). Gee agrees with this assessment, and asserts that one of the main concerns is that notions like communities and communities of practice imply that the intention is to label individuals who is included and who is excluded. In contrast, Gee's affinity space concept is one where, "people 'bond' first and foremost to an endeavor or interest and secondly, if at all, to each other" (p. 98).

Another section worth noting is the discussion on specialist language learning. In Chapter 9, Gee makes a distinction between everyday language, the "vernacular style," versus speaking technically or the "specialist style" (p. 106). Through an example of a mother having a conversation with her child about dinosaurs, fossils, and eggs, Gee reinforces the notion that even native English speakers need language learning in order to acquire and apply specialist language. He continues by stressing that until one has "played the game" the specialist language has no situated meaning. Further, Gee states, "School is too often about reading the manual before you get to play the game, if you ever do” (p. 116).

According to Gee, Chapter 10 is the "main piece in the book" (p. 6) in that it summarizes what he has been working on since his 2003 book, What Video Games have to Teach Us about Learning and Literacy. Gee hopes that this section will further the discussion and expand on the ideas presented in previous portions of this book. Unfortunately, Chapter 10 is repetitive not only in terms of his earlier work, but more importantly of this particular collection of essays. Gee acknowledges this and suggests that this review is designed to bring "together in one place the key themes, ideas, and issues” (p. 129). Because sections are copied verbatim from earlier chapters in this book, though, this style can be frustrating from a reader's perspective. Therefore, those who "fear repetition” (p. 130) should take Gee's advice and skip this portion of the book.

Repetition is not the only troublesome feature of this collection. While Gee makes a strong case for the use of affinity spaces instead of communities in Chapter 8, he loses sight of that message in Chapter 10. In this portion of the book, Gee makes no reference to affinity spaces, but continues to characterize these groupings as communities and communities of practice. This is evident in statements such as the one found in the section, "Video Games and Learning: A New Field." In this portion of the book, Gee states that games like World of WarCraft "are introducing new 'states' or 'communities' into the world” (p. 133). It is not clear why Gee defaults back to communities, but it does raise questions as to the applicability of the affinity spaces concept he so convincingly argues for in a prior chapter.

Gee suggests that gamers may agree that a particular game is good, but they "rarely think any one game is perfect" (p. 8). The discussion presented throughout this book, for the most part, is a good one, but like the video games Gee promotes, it is not perfect. While Gee's assessment of video games is thought provoking, the substantial amount of repetitive content is disappointing, particularly to individuals who are familiar with his earlier work. Those who are new to this topic, however, may find this tactic helpful in reinforcing the fundamental concepts associated with games and learning. Overall, this book and the ideas presented within its covers are accessible to a wide audience; this includes practitioners, college students, and academics alike. 


\section{References}

Gee, J. P. (2003). What video games have to teach us about learning and literacy. New York: Palgrave/ St. Martin’s.

Gee, J. P. (2007). Good video games + good learning: Collected essays on video games, learning and literacy. New York: Peter Lang.

Dede, C. (2005). Planning for neomillennial learning styles. Educause Quarterly, 28(1), 7-12. Retrieved October 31, 2007, from: http://www.educause.edu/ir/library/pdf/eqm0511.pdf

Kling, R., \& Courtright, C. (2003). Group Behavior and Learning in Electronic Forums: A sociotechnical approach. The Information Society, 19(3), 221-236.

Lave, J. (1996). Teaching, as learning, in practice. Mind, Culture, and Activity, 3, 149-164.

Prensky, M. (2001). Digital game-based learning. New York: McGraw-Hill.

Steinkuehler, C. A. (2005). Cognition and literacy in massively multiplayer online games. In D. Leu, J. Coiro, C. Lankshear \& K. Knobel (Eds.), Handbook of research on new literacies. Mahwah, NJ.: Erlbaum. Retrieved September 15, 2007, from http://labweb.education.wisc.edu/curric606/readings/Steinkuehler2005.pdf

Wenger, E. (1998). Communities of Practice: Learning, meaning, and identity. Cambridge: Cambridge University Press.

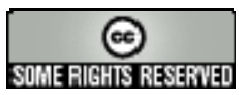

